\title{
Sciendo
}

RESEARCH PAPERS FACULTY OF MATERIALS

SCIENCE AND TECHNOLOGY IN TRNAVA

SLOVAK UNIVERSITY OF TECHNOLOGY

IN BRATISLAVA

2021, Volume 29, Number 48

DOI 10.2478/rput-2021-0001

\section{IMPORTANCE OF RECYCLING THE WASTE-CABLES CONTAINING COPPER AND PVC}

\author{
Lenka BLINOVÁ ${ }^{1}$, Peter GODOVČIN ${ }^{1}$ \\ ${ }^{1}$ SLOVAK University OF TECHNOLOGY In BRATISLAVA \\ FACULTY OF MATERIALS SCIENCE AND TECHNOLOGY IN TRNAVA \\ INSTITUTE OF INTEGRATED SAFETY \\ Ulica JÁna BotTu 2781/25, 91724 TRNAVA, SLOVAK REPUBliC \\ e-mail: lenka.blinova@stuba.sk, peter.godovcin@stuba.sk \\ Received 28 April 2021, Accepted 15 May 2021, Published 20 July 2021
}

\begin{abstract}
Urbanization, development of economy, increasing population and improved living standards and lifestyle have caused a sharp growth in waste. Inappropriate or inefficient waste disposal techniques can cause serious air, soil, and groundwater pollution, which subsequently can negatively affect the urban environment and threaten the health of residents. The goal of waste management is to move to a circular economy in which waste does not exist. If there is no possible way to reduce or reuse waste, the best solution is recycling it. Recycling brings abundant benefits on the economic and ecological levels levels, and helps reduce overall human health risk of adverse impacts. Recycling of the waste-cables which contain PVC and copper replaces the production of virgin PVC and mining of copper from copper ore, it reduces landfill solid waste pressures, saves energy and water sources, reduces emissions to environment, and also reduces negative impacts from improperly dispose of waste, etc. This paper presents an overview of recycling techniques for the waste-cables containing copper as a core and polyvinyl chloride as an insulating layer or sheath. It also lists advantages and disadvantages of these techniques and importance of recycling this type of waste.
\end{abstract}

\section{Keywords}

Waste-cables, recycling, copper, PVC, circular economy

\section{INTRODUCTION}

Rapid urbanization, population and economic growth are related to increased production of waste. The fact that we do not dispose or do not recycle it correctly, causes the release of large amounts of waste to the environment $[1,2]$. Every year, we dump a massive 2.12 billion tons of waste on the planet. This stunning amount of waste is partly because $99 \%$ of the things we buy is trashed within six months. Dumping waste and improper waste management have negative consequences on the planet, such as (i) pollution of soil (waste can leak hazardous chemicals into the soil and, from there, into our food) [3, 4], (ii) air pollution (the trash that is 
dumped in landfills releases methane gas; accidental fires of wastes at landfills release toxic substances into the air, including extremely poisoning dioxin) [2, 5], (iii) pollution of oceans (13 million tons of plastics end up in the world's oceans each year, if we keep throwing out plastics in the oceans, by 2050, there will be more plastics than fish in the sea; the plastic waste affects fish, seals, turtles, whales, and many other aquatic animals, as scientists have found many plastic fragments in over a thousand species that cannot distinguish between what is or is not food) [2, 6, 7], and (iv) pollution of groundwater (280 billion tons of groundwater is being polluted every year - that's 9,000 tons every second) $[8,9]$. Generally, the amount of waste generated affects the environment in multiple ways: it is contributing to the worsening climate crisis, it has a negative impact on wildlife and the natural environment, and is detrimental to our very own public health [2].

Households use a wide variety of electrical and electronic device (e.g. vacuum cleaners, washing machines, refrigerators, the gadgets, mobile phones, computers, televisions), while each of those products contain cables [10]. With the rapid development of the power and information technology industries, the production and application of cables have expanded [11]. Electrical wiring in a block of flats, but also in old family houses, today no longer meets current safety standards, and it is therefore necessary to replace it by a new one [12]. There are several causes why a large number of waste-cables is generated all around the world every year. About 70,000 tons of waste-cables containing copper and polyvinyl chloride (PVC) resources (or other materials) are disposed in landfills every year, and create local environmental burdens [13]. Therefore, the recycling and the reutilization of waste-cables has become an important topic not only in the field of environment protection [11, 13, 14].

Producing, consuming, and throwing products away is starting to affect our planet and our way of life. To ensure enough food, water, and prosperity for the years to come, we need to change it. We need to switch from a linear to a circular economy $[15,16]$.

\section{CHARACTERISTICS OF CABLES}

Cables are components that are used in the sectors of transport, construction, communication, and consumer goods $[11,13]$. Cables can be divided into five major categories, including magnetic wires, uninsulated wires, electrical wires and cables, power cables and communication cables, according to their structure, manufacturing process, function and usage characteristics. Depending on the final application of cable, cables can have different configurations, always basing their design on national and international regulations. Electric cables are measured in volts and, depending on these, they can be categorized into: low voltage cables (divided: up to $750 \mathrm{~V}$; up to $1,000 \mathrm{~V}$, also called $0.6 / 1 \mathrm{kV}$; used for industrial power installations in various fields such as industry, public installations, infrastructures, etc.), medium voltage cables (from $1 \mathrm{kV}$ to $36 \mathrm{kV}$; used to distribute electricity from electrical substations to transformer stations), high voltage cables (from $36 \mathrm{kV}$; used to transport electricity from the generating plants to the electrical substations). Depending of their use, the low voltage cables can be divided into cables for electric panels, power cables, armored cables, rubber cables, halogen-free cables, fire resistant cables, control cables, instrumentation cables, solar cables, special cables, and aluminum cables [17]. Depending on diameter of cables, they can be divided into thin (mm-order-diameter) and thick (cm-order-diameter) cables $[13,18]$.

Generally, the cable consists of an electric conductor (a conductive metal core such as copper, aluminum), insulation, auxiliary elements (to protect the cable and guarantee its longevity) and outer sheath (covers all the mentioned materials, while protecting them from the outside) $[13,17]$. The insulating layers are classified into two groups - thermoplastic (the most common are: PVC, polyolefins, linear polyethylene, polyurethane) and thermoset (the most common are: ethylene propylene, crosslinked polyethylene - XLPE, ethyl vinyl acetate, 
silicone, neoprene, natural rubber). In some cases, a cable may has metal shields - called armored cable (armors means mechanical protection that protects the cable from possible external aggressions: animals, physical damage, etc.; the cable can withstand higher stresses, which can make it suitable for direct burial, or allows it to be used in external underground and underwater projects) $[17,19]$.

The following Table lists selected cable types, their composition and approximate weight.

\begin{tabular}{|c|c|c|}
\hline \multicolumn{3}{|c|}{ PHELPS DODGE CABLE TYPE 60227 IEC 01} \\
\hline \multirow{2}{*}{ Annealed copper, PVC insulation } & & \multirow{2}{*}{ [111] } \\
\hline & Cable weight (approx.) [kg/km] $21-3,987$ & \\
\hline \multicolumn{3}{|c|}{ PHELPS DODGE CABLE TYPE 60227 IEC 10} \\
\hline \multirow{2}{*}{$\begin{array}{l}\text { Annealed copper, PVC insulation, PVC } \\
\text { inner sheath, PVC outer sheath }\end{array}$} & & \multirow[t]{2}{*}[112]{} \\
\hline & Cable weight (approx.) $[\mathrm{kg} / \mathrm{km}] 115-1,256$ & \\
\hline \multicolumn{3}{|c|}{ MEDIUM VOLTAGE CROSS-LINKED POLYETHYLENE CABLE } \\
\hline \multirow{2}{*}{$\begin{array}{l}\text { Conductor, Conductor shield, Insulation, } \\
\text { Insulation shield, Metallic shield, Filler, } \\
\text { Binding tape, Oversheath, Insulation: } \\
\text { XLPE }\end{array}$} & $\equiv$ & \multirow[t]{2}{*}{ [113] } \\
\hline & Cable weight (approx.) [kg/km] 1,705 - 13,010 & \\
\hline \multicolumn{3}{|c|}{ 0.6/1(1.2) kV FIRE RESISTANT LOW SMOKE \& HALOGEN FREE } \\
\hline \multirow{2}{*}{$\begin{array}{l}\text { Conductor, Fire barrier (mica tape), } \\
\text { Insulation, Inner sheath, Armour, } \\
\text { Binding tape, Outer sheath }\end{array}$} & & \multirow[t]{2}{*}[114]{} \\
\hline & Cable weight (approx.) $[\mathrm{kg} / \mathrm{km}] 274-8,440$ & \\
\hline \multicolumn{3}{|c|}{ PHELPS DODGE CABLE TYPE CV-AWA } \\
\hline \multirow{2}{*}{$\begin{array}{l}\text { Conductor, Cross-linked PE insulation, } \\
\text { PVC inner sheath, Aluminum wire } \\
\text { armour, Binding tape, PVC sheath }\end{array}$} & & \multirow[t]{2}{*}{ [115] } \\
\hline & Cable weight (approx.) $[\mathrm{kg} / \mathrm{km}] 136-7,344$ & \\
\hline \multicolumn{3}{|c|}{ MEDIUM VOLTAGE CROSS-LINKED POLYETHYLENE CABLE } \\
\hline \multirow{2}{*}{$\begin{array}{l}\text { Conductor, Conductor shield, Insulation, } \\
\text { Insulation shield, Copper tape, Bedding, } \\
\text { Aluminum tape, Binding tape, PE sheath, } \\
\text { Insulation: XLPE }\end{array}$} & 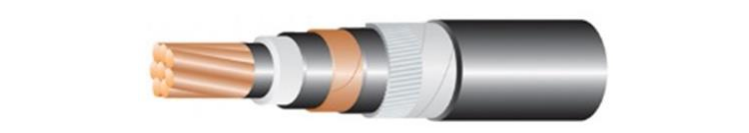 & \multirow[t]{2}{*}{ [116] } \\
\hline & Cable weight (approx.) $[\mathrm{kg} / \mathrm{km}] 800-13,505$ & \\
\hline \multicolumn{3}{|l|}{ FIGURE 8 AL-PE SHEATHED CABLE } \\
\hline \multirow[t]{2}{*}{$\begin{array}{l}\mathrm{PE} \text { or PP insulated conductor, Non- } \\
\text { hygroscopic tape, Aluminium shield, PE } \\
\text { sheath, Support messenger }\end{array}$} & & \multirow[t]{2}{*}{ [117] } \\
\hline & Cable weight (approx.) $[\mathrm{kg} / \mathrm{km}] 250-1,720$ & \\
\hline
\end{tabular}


There are a lot of types of cables of a different construction. Construction of cables depends on the type of cables and the environments of their utilisation (such as surrounding temperature, atmospheric humidity, altitude, water presence, presence of corrosive substances or stains, presence of vegetation or mold, seismic influences, air flow, etc.). For example, ELKOND HHK, a. s. Company, Slovakia, manufactured this kind of cables: Power cables with reaction to fire ( 6 types of cables), Control cables with reaction to fire (8 types), Communication cables (10 types), Control cables LF (4 types), Special conductors (5 types), Communication cables and conductors (6 types), Control cables (5 types), Power cables and conductors (flexible) (4 types), Power cables and conductors (for fixed installation) (2 types), Copper products (as copper wires, stranded copper wires, special copper rope), Power cables for fire protection of buildings in Czech Republic (6 types). Each type of cable has its basic characteristics (electric, fire-fighting) and construction, and can be manufactured in different varieties depending on number of cores $\times$ nominal cross-section $\left[\mathrm{n} \times \mathrm{mm}^{2}\right]$ [118].

By [119], for all cable types, the conductor makes up between 52 and $70 \%$ of the weight of the total cable for a given linear length of the cable. The percentage mass of insulation ranges from 10 to $21 \%$ of the cables, and jacketing (sheath) ranges from 19 to $34 \%$. Separators (also referred to as spacers or crosswebs) or other components constitute between 2 and $4 \%$ [119]. This statement probably applies to selected types of cables. This is confirmed, for example, by the \% results of 1-CXKH-V 3x1.5 P60-R cable composition (further referred to as $\mathrm{CXKH}$ ) and $\mathrm{N} 2 \mathrm{XH}-\mathrm{J}$ 3X1.5 RE (further referred to as N2XH) [120], which are listed in Table 1. These indicate different $\%$ shares of metal core, insulation and other components. This is also confirmed by the results of other authors. According to [121], the multiwire copper cable contains $25.4 \%$ of copper cords, $28.7 \%$ of tinned copper braids $(28.3 \%$ of Cu, $0.324 \%$ of Sn), $43.2 \%$ of PVC insulation (22.1\% of PVC, $11.5 \%$ of DEHP, $9.55 \%$ of filler $\mathrm{CaCO}_{3}$ ), $1.57 \%$ of polyester foil and $1.19 \%$ of cotton cords. According to [122], cable contains $26.9 \%$ of copper, $14 \%$ of insulation and $56.1 \%$ of sheath.

\begin{tabular}{|l|c|c|c|c|}
\hline Table 2 Basic parameters of the CXKH and N2XH cables [120] & \multicolumn{4}{l|}{} \\
\hline Electrical cable & CXKH & \% & N2XH & \% \\
\hline Mass of cable per unit length $(\mathrm{g} / \mathrm{m})$ & 150.0 & 100 & 148.3 & 100 \\
\hline Mass of outer sheath per unit length $(\mathrm{g} / \mathrm{m})$ & 45.5 & 30.3 & 44.1 & 29.7 \\
\hline Mass of bedding per unit length $(\mathrm{g} / \mathrm{m})$ & 54.2 & 36.1 & 55.2 & 37.2 \\
\hline Mass of insulation per unit length $(\mathrm{g} / \mathrm{m})$ & 9.3 & 6.2 & 10.7 & 7.2 \\
\hline Mass of glass mica tape per unit length $(\mathrm{g} / \mathrm{m})$ & 2.5 & 1.7 & - & - \\
\hline Mass of copper per unit length $(\mathrm{g} / \mathrm{m})$ & 38.5 & 25.7 & 38.3 & 25.8 \\
\hline
\end{tabular}

In this article, all products which consist of at least two layers, namely the conductor (e.g. copper, aluminum) and the insulating layer or sheath (made of plastic material), are considered as cables.

The common copper-containing cables typically consist of a conductive copper core, an insulating layer (PVC, polyethylene - PE), and a flame-retardant protection layer $[11,13]$. The purpose of the waste-cables recycling is to separate metals from insulating layer, sheath or another layer, and obtain high-purity materials. The waste-cables recycling enterprises use semi-mechanized or mechanized treatment techniques [11].

Copper is a versatile base metal that is very vital for different sectors and used in a variety of applications, e.g. for making pipes, electrical components, electrical cables and also for building constructions, production of industrial machinery, transportation vehicles, in architecture; it plays a key role in the worldwide information and communication technologies $[20,21,22]$. It is the best conductor of electricity after silver, as it encounters much less resistance compared with other commonly used metals (is used as standard benchmark to which 
other conductors are compared). It is the third most important industrial metal, just after iron and aluminum, in terms of consumption, due to its resistance to corrosion and its thermal and electrical conductivity. Also, is one of the most recycled metals [13, 21, 22]. Virtually all products made of copper can be recycled, as recycled copper loses none of its chemical or physical properties [22]. In 2018, an estimated 24.5 million metric tons of copper were consumed worldwide [20].

PVC is one of the most used thermoplastic material in respect to the worldwide polymer consumption. It has in fact several intrinsic characteristics which make it the ideal choice for a range of different applications - can be processed into a wide variety of short-life products (such as packaging materials used in food, cleansing materials, textile, and medical devices) and also long-life products (such as pipes, window frames, floors coverings) [23, 24]. PVC can be also used as insulation and/or sheathing for production of any type of the electric and data transmission cables [25]. Among the most interesting properties of PVC materials are processability, resistance to temperature, resistance to hydrocarbons, self-extinguish properties, fire resistance, insulating properties, flexibility, transparency, recyclability and it is light and easy to reuse $[25,26]$. The properties of PVC can be significantly influenced by using a combination of plasticizers, fillers, stabilizers and other additives [25, 27]. For example, plasticizers make PVC soft and bendable, which is an essential characteristic to produce cables and to ensure their durability for decades (PVC cables can last up to 80 years under normal conditions of use) [24, 28]. Different plastics are used as insulation and sheathing for electric cables, as well as the sheathing for telecommunication cables. Among these, the PVC is mostwidely used, because it is able to ensure the best cost/performance ratio, high sustainability and recyclability [25]. In 2016, the consumption volume of PVC reached 42,931.1 thousand tons, and it is forecast that the volume will increase up to 55,715 thousand tons in 2022 [29]. In 2017, the wires and cables made of PVC accounted for a seven percent of the total consumption of PVC worldwide [30].

\section{RECYCLING TECHNIQUES OF COPPER-CONTAINING WASTE-CABLES}

Nowadays, a lot of simple and convenient techniques are available for recycling thick waste-cables (they are easily stripped or crushed into small scrap nuggets and then sorted), while multi-step techniques are used to recycle thin waste-cables $[13,31]$. These multi-step techniques typically involve (i) mechanical treatment technology (such as stripping technology, crushing technology), ultrasonic separation, hot water treatment technology, cryogenic technology or high-pressure water jet technology combined with a technology for separation of copper and plastic particles, (ii) chemical technology (such as dissolution and cementation, chemical- or bio-leaching, or chloride volatilization), and (iii) energy/heat recovery processes (such as incineration and thermal decomposition) [13, 14, 31]. Separation can be performed through (i) gravity separation techniques (a gravity separator can use a combination of air, vibration and separation, based on density/size/shape difference [101, 102], such as air gravity separation [103], jigging separation, shaking table separation [104], etc.), (ii) electrostatic separation, and (iii) flotation, etc.

Mechanical treatment technology is widely used for waste-cables recycling. In the early stage, this technology requires manual rough sorting of waste-cables. Obtained copper core and plastic material are separately recycled. The most common used mechanical treatment technologies (Figure 1) include:

- Stripping technology: The working principle of stripping machine is relatively simple, but could be very time consuming, depending on the type of equipment used and the amount of scrap. The machine is mainly driven by a stepping motor and wheel-clamped cable movement [124]. The specific process is as follows: the cables are collected, 
sorted by diameters, and treated by a stripping machine (it removes the insulation from the cable, leaving a pure core). The stripping machine operates by stripping the insulation by a blade or a knife, while an operator feeds the cable into a feed port, and an electric motor pulls the wire through. The operator then peels the cable manually, or the insulation falls off, depending on the thickness of the cable and/or conditions [125, 126]. This type of machine is well-automated, but the application scale is deeply confined; it can be only applied to stripping a particular cable of certain diameter. Therefore, researchers and waste-cables enterprises have made significant improvement to the traditional wire strippers, by rendering the stripping technology more efficient and more practical [11].

- Crushing technology: Waste-cables are crushed into particles of particular size after passing the crushers and then separated (with sorting equipment) into a plastic material and a copper rice. The equipment (containing the crushing and sorting units) used in this type of treatment is commonly known as a "copper rice machine" [11].

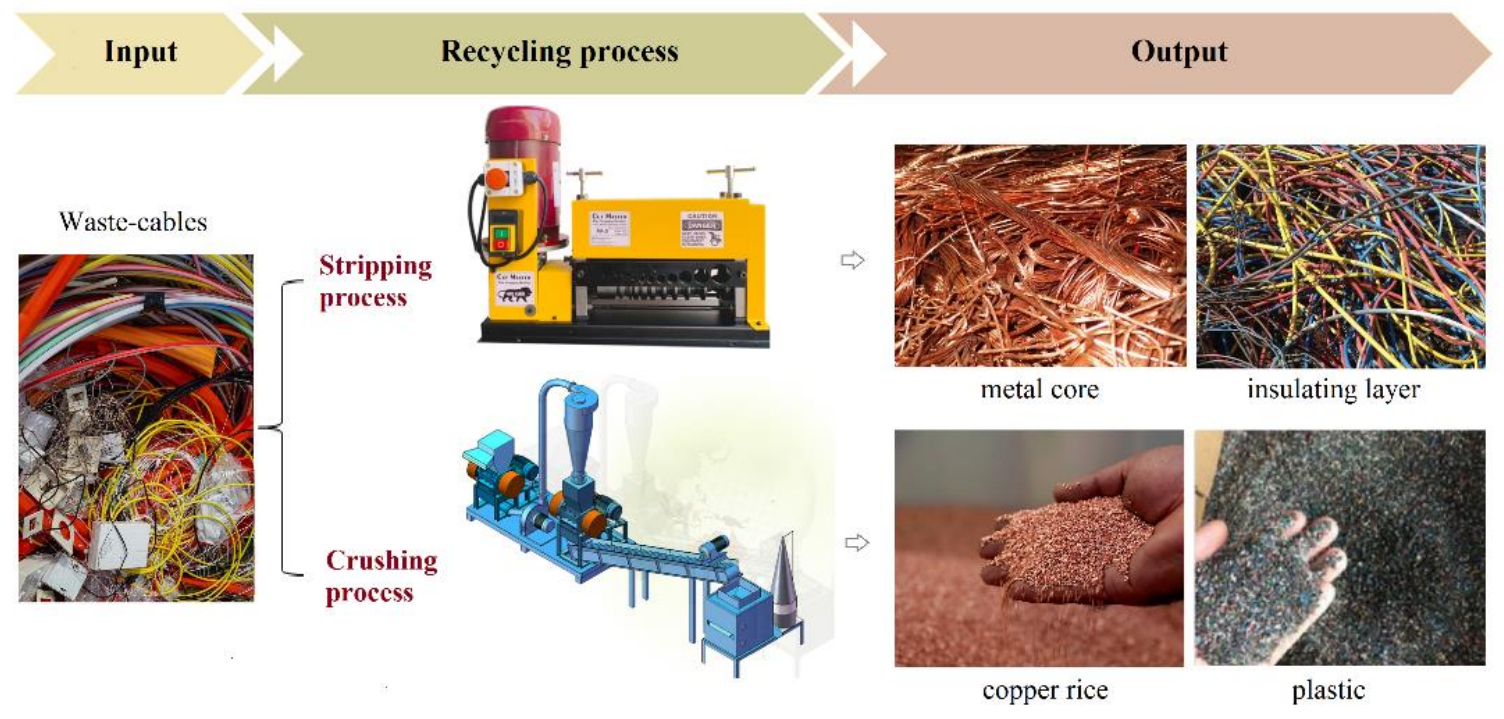

Figure 1 Mechanical treatment technology of cables (stripping and crushing process). Adapted from [92-96].

Capacity of the waste cable processing equipment varies (e.g. stripping machine: $100-300 \mathrm{~kg} /$ days [97], $200-1000 \mathrm{~kg} /$ day [98], crushing machine: $100-1000 \mathrm{~kg} / \mathrm{h}$ [99, 100]) and depends on several factors (e.g. degree of process automation, type of equipment, type of cable-single-core or multi-core, cable construction, diameter of cable, material used in cable, recycling purity of metal).

Figure 2 shows the process flow of waste cable treatment for one type of a copper rice machine. Based on the size and type of the treated waste-cables, the separation processes of the copper rice machine vary (e.g. the two-stage crushing + pneumatic separation, wet separation or electrostatic separation, three-stage crushing + two-stage separation) [11]. 


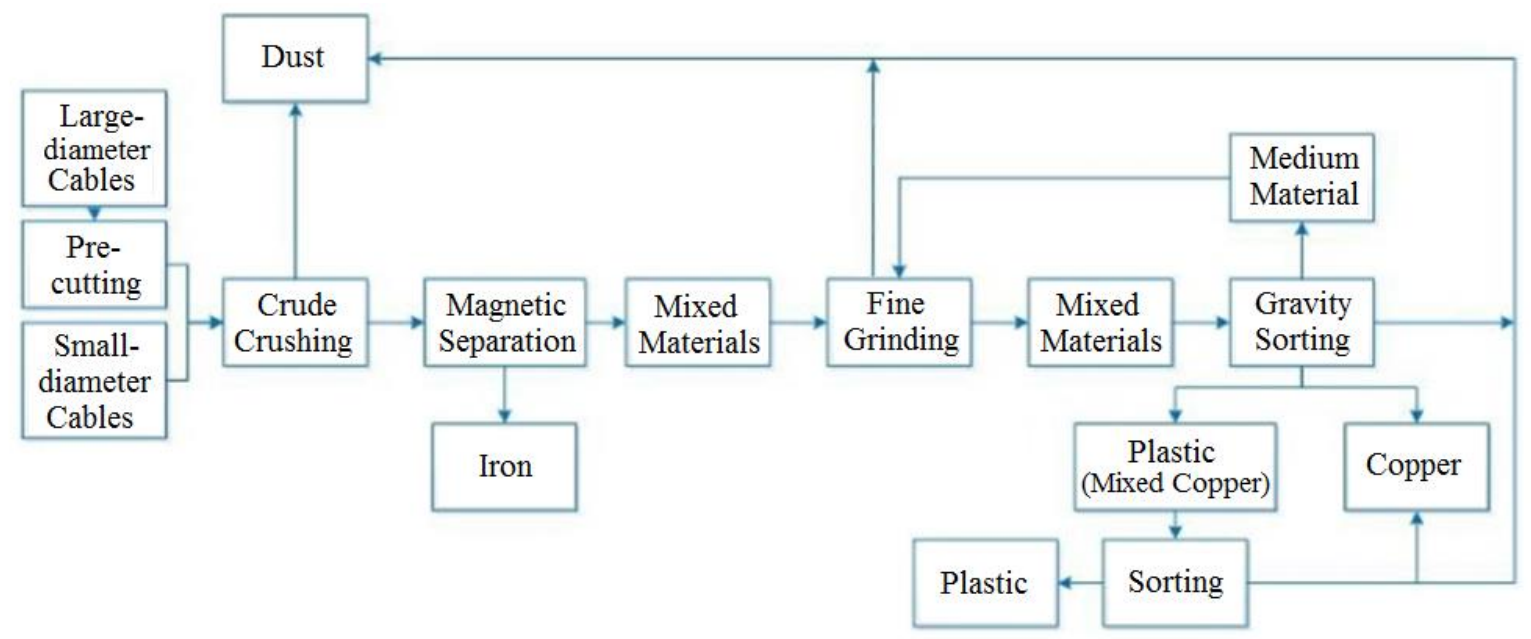

Figure 2 The process flow of waste-cable treatment for one type of copper rice machine. Adapted from [11].

In the cryogenic shredding technology (also as freezing process) shown in Figure 3, cables are treated with appropriate refrigerant (e.g. liquid nitrogen - is an inert substance) to make the plastic material more brittle, making it easy to crush, while the conductive copper core retains its strength. This process is suitable mainly for the waste-cables that cannot be easy to crush at the room temperature (cables containing e.g. polypropylene, low-density polyethylene, highdensity polyethylene, ultra-high molecular weight polyethylene) [11, 32, 33, 34, 35].

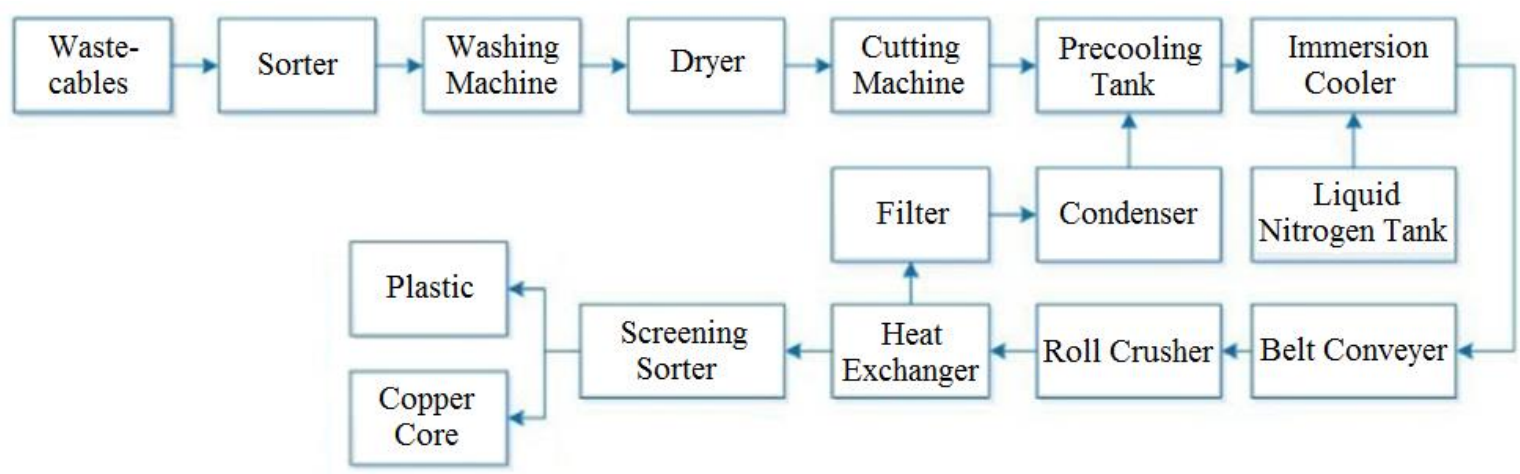

Figure 3 The process flow of waste-cable treatment through liquid nitrogen freezing technology. Adapted from [11].

In the high-pressure water jet cutting technology, the waste-cables move uniformly relative to the high-pressure water jet, and the huge energy produced by the water jet causes a pressure transient on the surface of the plastic sheath, resulting in its tearing in a very short time. This technique uses cold cutting and does not produce thermal deformation in the processing of waste-cables $[11,36]$.

A hot water separation technology can be used to recover metal and insulating material from cable-waste. Based on the differences in the thermal expansion coefficient of insulating material and copper, the cables are cut into a suitable length (with no need to grind the cable into smaller pieces) and placed into a blender with hot water. By controlling the water temperature, blending speed and cutting length, complete separation can be achieved [37].

The ultrasonic separation recycling uses the cavitation phenomenon induced by ultrasonic waves that goes through the water. The ultrasound cavitation effect causes the waste-cables 
immersed in water to sway and vibrate, to achieve the separation of the copper core and plastic sheath [38].

The separation of copper and plastics can be performed by mechanical/physical methods. The differences on the physical characteristics of materials in non-homogeneous compounds (such as magnetism, electric conductivity, density, etc.) are the bases of the mechanical/physical separation of them (e.g. magnetic separation, conductivity-based separation, sieving or densitybased separation). Magnetic separation is widely used for the recovery of ferromagnetic metals from non-ferrous metals and other non-magnetic materials [39]. Electric conductivity-based separation is used to separate materials (metals, non-metals) of different electric conductivity (or resistivity) [39, 40, 41]. There are three typical electric conductivity-based separation techniques: (i) Eddy current separation, (ii) Corona electrostatic separation, and (iii) Triboelectric separation [39, 42, 43]. The gravity separation (density-based separation) has large energy consumption and low efficiency, and therefore, over the last years, electrostatic separation technology has been researched and has compensated for the deficiency of gravity separation [11]. There are studies [43, 44, 45] that focus on estimating the optimal conditions of the process variables (e.g. electric field, splitter position, relative humidity) on the separation efficiency. One of serious problems is, if the waste contains multicomponent materials, because the presence of impurities greatly increases. The difficulty of their recycling leads to reduction of the quality of the obtained products. Therefore, accurate and efficient separation is an important pretreatment step in their subsequent recycling [14].

Some types of waste-cables are difficult to recycle by using the above-mentioned techniques, and therefore chemical treatment technology have been proposed. The traditional chemical treatment technology is a method in which the solid materials are immersed in a series of leaching solutions to obtain the metal; the target metal products are then obtained through the displacement, crystallization, extraction, or electrolysis of the leaching solution [11]. The technologies for the treatment of waste-cables include the dissolution and cementation or precipitation $[14,46]$, chemical leaching, and bio-leaching. The majority of these technologies focus on the recovery of copper without PVC treatment [14]. Given the waste-cables have a very high copper content, there is a high consumption of leaching solutions. Therefore, the technology is not suitable for the treatment in large numbers of waste-cables [11]. This technology can be used as secondary technology treatment if the plastic materials obtained from the mechanical/physical separation still contains some copper (low-copper-content wastecables) $[47,48]$. According to [11], chemical technology is to treat waste-cables by the use of salt solution or organic solvents which dissolve the plastic material, but do not react with the copper cores. Also, other specific methods can be used for recycling pure PVC and copper from the waste-cables (e.g. PVC swelling and mechanical agitation in hydrophobic organic solvent mixed with water, PVC swelling and rod milling, technique involving PVC embrittlement via plasticizer extraction and crushing by ball milling) [13, 14, 31, 49].

The following Figure shows the flowchart of metals recovery from the mixture of the electronic waste and sulphidic tailings. 


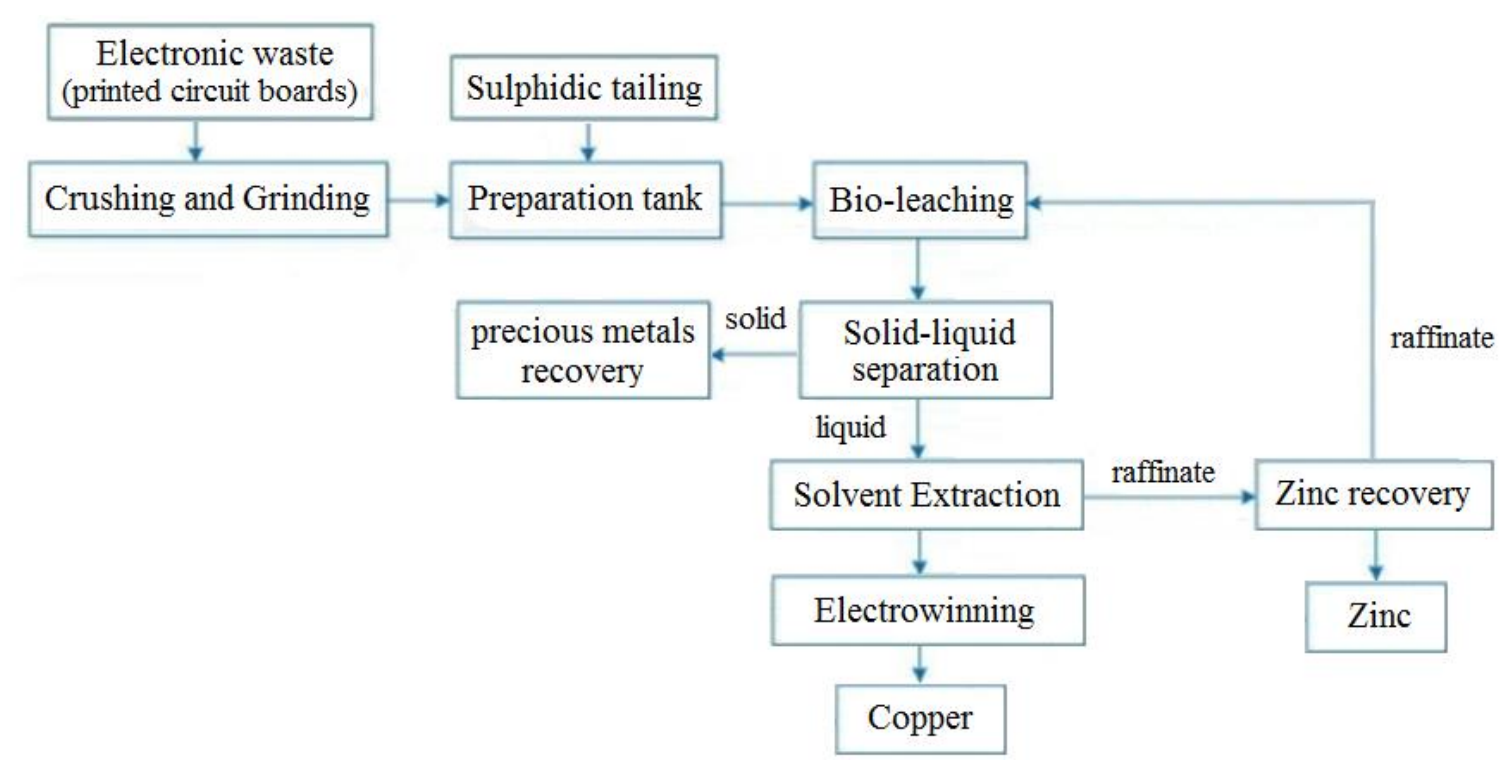

Figure 4 The flowchart of metals recovery from a mixture of the electronic waste and sulphidic tailings. Adapted from [123].

Energy/heat recovery processes include incineration and thermal decomposition. In the beginnings of waste-cables recycling, the main process was incineration. This process is simple (the plastic material of waste-cables is burned directly in an incinerator to recycle copper) and suitable for treating waste-cables of various specifications [13, 50]. Given the incineration problems (such as oxidation of copper and the formation of toxic gases), this process is eliminated in many countries. The problems can be solved by performing the pyrolysis (at 500$900{ }^{\circ} \mathrm{C}$ ) in the absence of oxygen $[11,13,14]$ or by other methods (e. g., using the induction heating voltage method or using high temperature steam gasification) [11, 51]. A pyrolytic gas (fuel gas), fuel oil, and carbon black are obtained from pyrolysis of waste-cables sheaths, and copper remains in the metallic state $[11,14]$.

The various types of metals and plastics are used for producing cables, and this fact can pose a problem during recycling. Therefore, the recycling process should be proposed as a treatment and separation of all types of materials as mixture (regardless of the type or the thickness of the insulating layer or metal core). The first step of separation is to divide materials into non-metals and metals, and then separate based on the type (PVC, PE, rubber or copper, aluminum). For example, aluminum and copper can be sorted using a roll-type electrostatic separator equipped with a reversed-S-shaped-plate high-voltage electrode at very high degrees of purity [52], density-based separation, sorting by using eddy current separation [53], or highresolution optical sorting system [54]. For separation of different plastics for example triboelectrostatic separation can be used $[55,56]$, as well as selective flotation separation [57, $58]$, or laser-induced plasma spectroscopy $[59,60]$, etc. There is need to use a combination of various treatment technologies to obtain materials with very high purity.

About 30 entities in the Slovak Republic deal with recovery of waste from ferrous and nonferrous metals, including waste-cables treatment. Waste from ferrous and non-ferrous metals are a commodity with the network of collection and repurchase centers, which can be characterized as over dimensioned in many locations [61]. Many different technologies of waste-cables treatment are used such as crushing and subsequent separation of material components by means of a machine with a vibrating plate [62]; mechanical grinding and granulation with subsequent separation of materials based on fluid separation [63]; or crushing to the required fraction and subsequent separation by air flow [64]. 


\section{ADVANTAGES AND DISADVANTAGES OF RECYCLING TECHNIQUES}

Each techniques of waste-cables recycling has its own advantages, disadvantages, and its own scope of application. Although the process for each waste-cables recycling technology vary, the aim is the same - to separate the copper core and plastic sheath.

The mechanical treatment technology is a simple low-cost process that is the most widely used. The process has also disadvantages such as dust and noise pollution; the application scale can be deeply confined (e.g. only applies to the stripping for a particular cable with certain diameter); the crushing can requires initial manual cutting and lead to severe human resource waste and extremely low efficiency; in the operation of the copper rice machine, the friction between the equipment and waste-cables produces high temperature and heat, resulting in wearing and even operational failure of the copper rice machine. Therefore, the development of high efficiency and low consumption waste-cables cutting, and sorting technology and equipment is very significant for improving this industry's efficiency and working conditions [11]. The cryogenic shredding technology (the utilization of liquid nitrogen) has undoubtedly numerous advantages in the treatment of waste cables, such as readily available, easy handling, low technical input, easy control, good heat transition, low dust and noise pollution, low crushing force and the fact that heat-sensitive materials will not oxidize and deteriorate (no loss of copper, high-quality plastic recycling). The main disadvantage is the high operation costs caused by using liquid nitrogen. Therefore, it is imperative to develop efficient refrigeration technology and optimize the process flow of cryogenic grinding to decrease the cost $[11,32]$. The ultrasonic separation recycling and the high-pressure water jet cutting are a green recycling technologies that does not change the physical and chemical properties of copper and plastic, and have excellent environmental benefits (such as high recovery rate, low energy consumption, etc.) $[11,37,38]$. The main problem of these treatment technologies is that processing scale is small and its difficult to achieve industrialization. Adaptability of chemical treatment technology is low; the required chemical regents depend on the composition of the plastic material in waste-cables; the treatment process consumes a large quantity of solvents and thus can easily lead to secondary pollution. Because of these concerns, further improvements are imperative for the industrialization of chemical methods. The advantage of this technology is obtaining high degree of plastic resources [11]. Incineration is a simple treatment technology, but has a lot of disadvantages such as that the surface of the copper core after treatment is severely oxidized $[11,13,14]$, largely decreasing the copper's purity (recycled copper cannot be directly used for processing copper products and must go through smelting and electrolysis which increases the processing steps and costs of process) $[11,105]$. In addition, the oxidized copper components of cables become part of toxic metal compound in the bottom and fly ashes (e.g. as copper metal, copper oxides, mixed oxides [107], copper sulfides [108]; copper in oxidation states $0,+\mathrm{I}$ and +II [107]; $\mathrm{CuO}$ [109], $\mathrm{Cu}_{2} \mathrm{O},(\mathrm{Co}, \mathrm{Cu})_{2} \mathrm{O}$, $(\mathrm{Cu}, \mathrm{Zn}) \mathrm{O},(\mathrm{Mg}, \mathrm{Fe}, \mathrm{Zn}) \mathrm{O},(\mathrm{Mn}, \mathrm{Fe}, \mathrm{Cr}, \mathrm{Ni}, \mathrm{Cu}, \mathrm{Zn})_{2}(\mathrm{Al}, \mathrm{Ti}, \mathrm{Fe}) \mathrm{O}_{4}, \mathrm{CuS},(\mathrm{Cu}, \mathrm{Fe}) \mathrm{S}, \mathrm{Fe}_{\mathrm{x}} \mathrm{Cu}_{\mathrm{y}} \mathrm{S}$ [108], $\mathrm{CuCl}_{2} \cdot 3 \mathrm{Cu}(\mathrm{OH})_{2}, \mathrm{CuCl}, \mathrm{Cu}(\mathrm{OH})_{2} \cdot \mathrm{CuCl}_{2} \cdot 3 \mathrm{Cu}(\mathrm{OH})_{2}$ [110], etc.), which prevent their use as metal materials [14]. Given that the main components of the plastic sheath in waste-cables are thermoplastics (such as PVC, PE) and flame retardants, the smoke and gas produced from the incineration process contain toxic gas (contains e. g. polycyclic aromatic hydrocarbons, polychlorodibenzo-p-dioxins, polychlorodibenzo-furans, chlorobenzenes, chlorophenols, chlorobiphenyls) and dust $[11,13,14,50]$. This could be especially hazardous when the process is uncontrolled. Illegal recycling, open burning at landfills or accidental fires can causing severe deterioration to the environment and harm to human health [50]. The incineration in controlled atmosphere incinerators should be safe because there are effective flue gas cleaning systems utilized [106]. Developing others new environmentally friendly incineration technologies to improve existing technologies is still a must. By using a thermal recovery process to treat waste- 
cables, maximal recycling and harmless disposal can be achieved [11]. Pyrolysis of waste plastics containing PVC could provide alternatives that replace natural gas and propane; however, pyrolysis is associated with high-energy costs required for heating [13].

For effective treatment of waste-cables is very important to choose suitable technology. The goal is obtaining the highest possible purity of the separated metals and plastics, and the copper content in the separated plastic should be as close to $0 \%$ as possible. The best choice would be the technology that can treat various type of cables regardless of the type of cable, material of core or sheath, diameters, etc. The technology of treatment should be effective, fully automatized, environmentally friendly, and economically advantageous.

\section{RECYCLING - A STEP TOWARDS A CIRCULAR ECONOMY}

The waste-cables are generated in more ways, such as during manufacturing process of cables (cables with insulating material defects), owing to the end-of-life of cables (obtain during repair buildings and electro-installation) or end-of-life of electric and electronic equipment. These waste-cables are a big part of problem and create a serious waste management issue [14, 35]. Managing waste in a more efficient manner is the first step towards circular economy [65].

The circular economy is rethinking production and consumption patterns to limit waste and thus optimize the use of resources. The old economic model of extracting, producing, consuming, and disposing can no longer apply if we want to protect our planet. To effectively reduce its disastrous environmental consequences requires a change in the economy. Making the circular economy therefore means repairing, recycling, and reusing instead of throwing away, but also understanding the limits of natural resources [66]. Reusing, redistributing and/or remanufacturing strategies are the preferred approaches in a circular economy, as they are based on parts durability [67, 68]. Caring for and preserving the value of product components increases corporate economic resilience, while diminishing external market risks [68]. However, the recycling of materials from waste is necessary for the circular economy due "to close the loop" [69].

The priority should be to discourage non-essential production and unnecessary consumption or use [70]. Next, very important step is increasing of recycling, because generally recycling rates globally are low. The circular economy is developing but the official model is not yet in place [66]. Transitioning an economic model from linear to circular requires the involvement and commitment of several stakeholders, such as producers, consumers, and policymakers [71].

The most valuable component of the waste-cables that should be recycled is non-ferrous metals (e.g. copper, aluminum; the plastic insulated waste-cables contains 40-90 wt. \% of metals). Next, thermoplastic insulator or sheath (e.g. PVC, PE) can be granulated and reused. Recovery of metals and plastics have economic and ecological reasons [13, 35]. If this type of waste ends up in a recycling plant, its correct treatment is ensured and there is no danger that the material ends up as waste on landfills or will be sent and accumulated in underdeveloped countries.

Without recycling, valuable copper core and plastic from cable would end up in landfills, which are becoming too full to accommodate more waste. The demand for space in landfills is high, making the cost of dumping waste very expensive. Additionally, buried metals and plastics could contribute to environmental harm. [14, 72, 73]. Results from study [74] indicate that several years after the closure of the landfill, elevated concentrations of metals (e.g. iron, copper, nickel, zinc) are found in the soils and this mean that landfills can be potential sources of toxic metals to the environment. By [75], metals (e.g. copper, cadmium, lead) were present in leachate, soil, and in plants that were growing at the landfill. Well-managed landfills are usually surrounded by protective lining to prevent water leaking to the surrounding 
environment. However, local pollution can occur where this is not implemented effectively, or the lining breaks down and is not replaced [73]. According to extensive international research project on the long-term behavior of PVC products in landfills and underground (conducted by the Technical University Hamburg-Harburg, the University of Linköping, and Chalmers University in Göteborg) PVC products stored in landfills are not posing a risk to human health and the environment. Toxic metal stabilizers may in fact reach the water of landfills in small amounts but are more or less insignificant in comparison to toxic metals from other sources in municipal waste. It is similar to plasticizers which can migrate from soft PVC through microorganisms. They are broken down and do not lead to a toxically relevant deterioration of the leakage water $[76,77]$. By [78, 79] dumping of PVC in landfills poses significant long-term environmental threats due to leaching of toxic additives into groundwater (depending on contains plasticizers, metal-based stabilizers, or type of landfill). There are also risks that PVC can be burned in a landfill fire where it produces toxic air pollutants (such as dioxin) that can contribute to unhealthy air and may subsequently enter the food chain [77]. In principle, valuable materials such as plastics or metals should not end up in landfills [76].

In underdeveloped countries, electric waste, and electronic equipment waste (such as mobile printed circuit boards, computer, and waste-cables) are recycled by simply burning them. The copper remains solid and can be collected after burning. Open burning of this type of waste has a direct environmental impact because it releases toxic emissions to the surrounding environment (e.g. incomplete combustion of PE, polypropylene and polystyrene can release carbon monoxide and noxious emissions, while PVC can produce dioxins [73]). The deposition of the contaminants in soil, sediments, or water accounts for the indirect impact $[35,80]$. In some part of the world (e.g. in Ghana, China, India, Nigeria, and the Philippines), the informal workers (usually children and adolescents) work for 10-12 $\mathrm{h}$ per day and incessantly burn the wires and cables with insulating layer from PVC. This results in the immediate environment being overwhelmed by thick black smoke, which takes a long time to clear $[80,81,82]$. Workers usually do not wear protective equipment and lack any awareness of handling dangerous materials [81]. In addition, it is uneconomical to recover only the metals, without considering the material of insulating layer or sheath. [35] The correct recycling of waste-cables allows all of waste (both metals and plastics) to be used perfectly for other purposes.

Copper is a $100 \%$ recyclable material (copper does not lose its quality and functionality during recycling in comparison to that from ore and can be reused multiple times, therefore a significant part of copper originates from recycling). Recycling copper significantly contributes to natural resources conservation, waste minimization, energy savings, and cost reduction. There are so many advantages to recycling copper that the value of scrap is approximately $85-95 \%$ the price of newly mined ore [21, 48, 83, 84, 85]. Copper is a trace element that is essential for plant and animal health therefore it is important for some copper to remain in its natural state (recycling contributes to conservation this resources). Copper ore is a finite, nonrenewable resource, so once it has all been mined, it will be gone. Currently, only about $12 \%$ of known copper resources have been mined and consumed [86]. During mining and refining (purification) of copper, dust and waste gases such as carbon dioxide or sulphur dioxide are produced, which may have a harmful effect on the environment (e.g. sulfuric acid are produced when sulphur dioxide combines with water and air; this is the main component of acid rain and can cause deforestation and the acidification of waterways, which can be deadly for aquatic life). During copper recycling, there are little, if any, harmful gases emitted (e.g. by using copper scrap, we reduce $\mathrm{CO}_{2}$ emissions by $65 \%$ ) [21, 83, 84, 85, 86]. The recycling of copper helps to meet the growing demand for copper [84]. According to [83, 84, 85, 86], recycling copper uses only about $10-15 \%$ of the energy necessary for extraction copper from ore. The conserving energy is very beneficial to the environment because leads to the conservation of 
valuable reserves of oil, gas or coal $[84,85,86]$. The copper recycling process is much less expensive than the process of extracting and refining new copper, and this means that products from recycled copper are more affordable [86].

PVC has the longest history of recycling of all plastics. Recycling this material has many environmental and social benefits (e.g. PVC can be recycled by advanced mechanical recycling systems, large volumes of recyclable PVC waste are available, using recycled PVC helps meet resource efficiency objectives and allows for the preservation of raw materials, or using recycled PVC reduces emission and landfill requirements, etc.) [46]. PVC can be recycled repeatedly up to 8 times depending on the application, without any indication of damage to its structure (the recycling does not measurably decrease the chain length of PVC molecules) $[46,87]$. One of the special advantages of PVC compared to other materials is the possibility of changing the formulation to improve the safety and eco-efficiency of the final product, while maintaining the same level of technical performance [88]. This process can be limited due to the presence of some additives (e.g. chlorine, cadmium, lead) [89]. Using recycled PVC helps meet resource-efficiency targets. The energy demand from recycled PVC is typically between 45-90\% lower compared to its production from virgin materials [87, 89, 90]. This reduce reliance on fossil fuels and protect ecosystem from the pollution that can be generated in the process virgin PVC [87]. According to [91], the recycled PVC reduces global warming potential by $39 \%$ and water consumption by $72 \%$. For each ton of PVC recycled, approximately 2 tons of $\mathrm{CO}_{2}$ are saved (the almost 770,000 tons of PVC recycled in 2019 saved 1.5 million tons of $\left.\mathrm{CO}_{2}\right)[89,90]$. Cost-benefit analysis of recycling the PVC waste showed that recyclation of PVC waste was preferable and more economically efficient than incineration or landfilling, and it also creates more jobs than any other end-of-life option [79]. The 740,000 tons of PVC recycled in 2018 contributed to the creation of more than 1,500 direct jobs in recycling plants in Europe. By 2030, about 200,000 new jobs will be created, because sorting and recycling capacity in the European recycling industry is expected to significantly increase [89].

The aim of circular economic at treatment of waste-cables is to recover, recycle and reuse all waste materials generated in the different phases of them treatment.

\section{CONCLUSION}

Without wires and cables, our society, as we know it, would not exist because a lot of applications depend on them (such as electricity, electronics, transports, information technology, home automation). The waste cables are generated in more ways, such as during the manufacturing process of cables, owing to the end-of-life of cables or end-of-life of electric and electronic equipment. There is a lot of types of wires/cables of various construction, containing various parts (such as electric conductor, insulation, auxiliary elements and outer sheath) and various kinds of materials (e.g. copper, aluminum, PVC, PE, natural rubber, mica tape). Recovery of metals and plastics from waste cable have economic and ecological reasons - copper and PVC are recyclable material, and their recyclation significantly contributes to the natural resources conservation, waste minimization, energy savings, and cost reduction. When this type of waste ends up in a recycling plant, its correct treatment is ensured, and there is no danger that the material ends up as waste in landfills, or will be sent and accumulated in underdeveloped countries.

Various technologies can be used to recycle waste cables. The most common waste cable recycling technology is that of mechanical recycling, which primarily involves cable stripping and crushing. This technology is simple, low-cost and has strong adaptability. In addition to its advantages, it also has its limitations, e.g. high energy consumption, high dust and noise pollution, the technology requires initial manual cutting and leads to severe human resource waste and extremely low efficiency. The advantage of stripping technology is that there are 
lower material losses because we get bigger pieces of metal core and plastic and the disadvantage is that can be applied to stripping for a particular cable with a certain diameter. For crushing technology the main advantage can be considered a larger amount of processed cable waste per day, the disadvantage is e.g. higher energy consumption when crushing cables during processing. Compared to mechanical treatment technology, cryogenic shredding technology, ultrasonic separation recycling and high-pressure water jet cutting all have various advantages, including high recycling efficiency, excellent environmental benefits, and highquality products (copper and plastic does not change the physical and chemical properties during recycling). Their main problem is that the processing scale is small and it's difficult to achieve industrialization. Some types of waste cables are difficult to recycle by using the abovementioned techniques, and therefore chemical treatment technology has been proposed. If the aim of chemical technology is obtaining copper, the technology is not suitable because there is a large amount of metal in waste cables - it means that process consumes a large number of solvents/leaching solutions and thus can easily lead to secondary pollution. A better choice is to use this technology as a secondary technology treatment if the plastic materials obtained from the mechanical/physical separation still contain some copper (low-copper-content waste cables). Another treatment technology is incineration. This technology is simple and one of its disadvantages is that the surface of the copper core after treatment is severely oxidized - thus decreasing the copper purity. Another problem can be uncontrolled incineration (e.g. illegal recycling, open burning at landfills, or accidental fires). The cable sheath contains thermoplastics and flame retardants and the smoke and gas produced from the incineration process contain toxic gas and dust which can cause severe deterioration to the environment and harm to human health. Also, other methods can be used for recycling pure PVC and copper from the waste cables (e.g. PVC swelling and mechanical agitation in hydrophobic organic solvent mixed with water, PVC swelling and rod milling, a technique involving PVC embrittlement via plasticizer extraction and crushing by ball milling).

It is not very difficult to recycle clean and homogeneous waste, but there can be problems with composite products which contain various types of plastics and metals. In such case, it is necessary to maximize the separation efficiency and subsequently the quality of recovered products from various types of waste-cables. Therefore, for example, the multi-stage separation and optimization of the processing conditions must be included in the waste recovery process. For effective treatment of waste-cables, it is important to choose a suitable technology. The best choice would be the technology that can treat various types of cables regardless of the type of cable, material of core or sheath, diameters, etc. The technology of treatment should be effective, full automated, environmentally friendly, and economically advantageous.

Human health is at risk through our inaction, because we keep producing large amounts of wastes which are disposed by inappropriate or inefficient techniques. According to [39], only in Germany alone, about 150,000 tons of waste-cable is generated annually. Every year, it is a large amounts of waste generated in the world. From this waste we can obtain valuable materials such as copper or plastic. It is necessary to avoid throwing out the waste which can be recycled. We cannot prevent or promote longevity with how we treat our Earth. It is necessary to produce it in a sustainable way, while limiting consumption and waste - this is the aim of circular economy. In the circular economy, production and consumption are regulated in such a way that products can be reused, repaired and recycled. According to [66], throwing and wasting are no longer trivial acts today, and it is deplorable that they have been.

\section{Acknowledgement}

The research was supported by the Slovak Research and Development Agency under the contract No. APVV-16-0223. 


\section{References}

[1] SINGH, J. et al. 2014. Progress and challenges to the global waste management system. Waste Management \& Research, 32(9), 800-812. ISSN 0734-242X.

[2] DOWNS, A., ACEVEDO, R. How our trash impacts the environment [Online]. 2019 [Accessed: 03-2021] Available at https://www.earthday.org/how-our-trash-impacts-the-environment/.

[3] WUANA, R. A., OKIEIMEN, F. E. 2011. Heavy Metals in Contaminated Soils: A Review of Sources, Chemistry, Risks and Best Available Strategies for Remediation. International Scholarly Research Notices, 2011, 1-20. ISSN 2356-7872.

[4] FAZEKAŠOVÁ, D., FAZEKAŠ, J. 2020. Soil quality and heavy metal pollution assessment of iron ore mines in Nizna Slana (Slovakia). Sustainability, 12, 1-15. ISSN 2071-1050.

[5] GANGWAR, C. et al. 2019. Assessment of air pollution caused by illegal e-waste burning to evaluate the human health risk. Environment International, 125, 191-199. ISSN 0160-4120.

[6] SHARMA, A. et al. 2019. Recovery of plastics from dumpsites and landfills to prevent marine plastic pollution in Thailand. Waste Disposal \& Sustainable Energy, 1, 237-249. ISSN 25247891.

[7] European commission. Plastic waste: Ecological and human health impacts (in-depth report). [Online]. 11/2011 [Accessed: 03-2021] Available at https://ec.europa.eu/environment/integration/research/newsalert/pdf/IR1_en.pdf.

[8] STEFANIA, G. A. et al. 2019. Identification of groundwater pollution sources in a landfill site using artificial sweeteners, multivariate analysis and transport modeling. Waste Management, 95 , 116-128. ISSN 0956-053X.

[9] www.theworldcounts.com, Tons of waste dumped. [Online]. [Accessed: 03-2021] Available at https://www.theworldcounts.com/challenges/planet-earth/waste/global-waste-problem/story.

[10] European Environment Agency. Europes consumption in a circular economy: the benefits of longer-lasting electronics. [Online]. [Accessed: 03-2021] Available at https://www.eea.europa.eu/publications/europe2019s-consumption-in-a-circular.

[11] LI, L. et al. 2017. Overview of the recycling technology for copper-containing cables. Resources, Conservation \& Recycling, 126, 132-140. ISSN 0921-3449.

[12] HARTMANNOVÁ, V. Replacement of electrical wiring in the apartment, house, apartment building. What is the price of a permit? (Výmena elektrických rozvodov v byte, dome, bytovom dome. Aká je cena, treba povolenie?). [Online]. [Accessed: 03-2021] Available at https://www.topbyvanie.sk/magazin/vymena-elektrickych-rozvodov.

[13] XU, J. et al. 2019. Separation of copper and polyvinyl chloride from thin waste electric cables: A combined PVC-swelling and centrifugal approach. Waste Management, 89, 27-36. ISSN 0956$053 \mathrm{X}$.

[14] LU, J. et al. 2019. Separation mechanism of polyvinyl chloride and copper components from swollen electric cables by mechanical agitation. Waste Management, 93, 54-62. ISSN 0956$053 X$.

[15] Government of the Netherlands. From a linear to a circular economy. [Online]. [Accessed: 032021] Available at https://www.government.nl/topics/circular-economy/from-a-linear-to-acircular-economy.

[16] VALACHE, C. Circular Economy: What It Is and Why We Need It? [Online]. 2020 [Accessed: 03-2021] Available at https://interestingengineering.com/circular-economy-what-it-is-and-whywe-need-it.

[17] www.topcable.com, Electrical Cable Types, Sizes, and Installation. [Online]. 2020 [Accessed: 03-2021] Available at https://www.topcable.com/blog-electric-cable/en/electrical-cable-types/.

[18] XU, J. et al. 2018. Simultaneous recovery of high-purity copper and polyvinyl chloride from thin electric cables by plasticizer extraction and ball milling. RSC Advances, 8, 6893-6903. ISSN 2046-2069.

[19] PINDAR, J. Armoured Cable-Wire or Tape? [Online]. 2020 [Accessed: 03-2021] Available at https://www.webro.com/armoured-cable/.

[20] GARSIDE, M. Global refined copper consumption distribution by region 2019. [Online]. 2020 [Accessed: 03-2021] Available at https://www.statista.com/statistics/693466/distribution-ofglobal-refined-copper-consumption-by-region/. 
[21] www.euric-aisbl.eu, Metal Recycling Factsheet. [Online]. [Accessed: 03-2021] Available at https://www.euric-aisbl.eu/position-papers/download/591/335/32.

[22] International Copper Study Group. The World Copper Factbook 2014. [Online]. [Accessed: 032021] Available at https://copperalliance.org/wp-content/uploads/2012/01/ICSG-Factbook2014.pdf.

[23] SADAT-SHOJAI, M., BAKHSHANDEH, G. R. 2011. Recycling of PVC wastes. Polymer Degradation and Stability, 96(4), 404-415. ISSN 0141-3910.

[24] www.electricalengineeringmagazine.co.uk, PVC Wires and Cables: Bringing Essential Benefits to Society. [Online]. 2018 [Accessed: 03-2021] Available at https://www.electricalengineeringmagazine.co.uk/news/pvc-wires-and-cables-bringingessential-benefits-to-society/.

[25] PVC4cables. The production of PVC cables: past and future of the value chain. [Online]. [Accessed: 03-2021] Available at https://www.pvc4cables.org/images/THE PRODUCTION OF PVC CABLES.pdf.

[26] WADE, S. 3 Key Benefits of PVC Wiring. [Online]. 2016 [Accessed: 03-2021] Available at https://www.vinylinfo.org/news/3-key-benefits-of-pvc-wiring/.

[27] KACZOREK-CHROBAK, K., FANGRAT, J. 2020. PVC-Based Copper Electric Wires under Various FireConditions: Toxicity of Fire Effluents. Materials (Basel), 13(5), 1111. ISSN 19961944.

[28] PVC4cables. PVC wires and cables: bringing essential benefits to society. [Online]. [Accessed: 03-2021] Available at https://www.pvc4cables.org/en/media-en/news/item/115-pvc-wires-andcables-bringing-essential-benefits-to-society.

[29] GARSIDE, M. PVC consumption volume worldwide 2016-2022. [Online]. 2018 [Accessed: 032021] Available at https://www.statista.com/statistics/887934/polyvinyl-chloride-consumptionvolume-worldwide/\#statisticContainer.

[30] TISEO, I. Distribution of global PVC use by end use 2017. [Online]. 2021. [Accessed: 03-2021] Available at https://www.statista.com/statistics/615454/distribution-of-pvc-consumptionworldwide-by-end-use/.

[31] XU, J. et al. 2018. Validation of a deplasticizer-ball milling method for separating $\mathrm{Cu}$ and PVC from thin electric cables: A simulation and experimental approach. Waste Management, 82, 220 230. ISSN 0956-053X.

[32] WILCZEK, M. et al. 2004. Optimised technologies for cryogenic grinding. International Journal of Mineral Processing, 74S, S425-S434. ISSN 0301-7516.

[33] www.zeusinc.com, Low temperature properties of beta-aluminas. [Online]. 2005. [Accessed: 032021] Available at http://minhajaneladepvc.com.br/uploads/plastics_low_temp - spaghetti.pdf.

[34] https://patents.google.com, CN101404194A: Method and device for stripping outer casing of waste plastic wire by utilizing liquid nitrogen low temperature technology. [Online]. 2008 [Accessed: 03-2021] Available at https://patents.google.com/patent/CN101404194A/en.

[35] MOKSIN, V. et al. 2011. Method of removal of the plastic insulator from waste cables by passing them between two rotating rolls that have different surface temperatures. In: Environmental Engineering. The 8th International Conference: Lithuania, Vilnius, pp. 228-232. ISBN 978-995528-827-5.

[36] https://patents.google.com, CN103198906A: Waste wire recovery method based on highpressure water jet and waste wire recovery device based on high-pressure water jet. [Online]. 2013. [Accessed: 03-2021] Available at https://patents.google.com/patent/CN103198906A/en.

[37] SHING- WEN, S., MIN-SHING, T. 2008. Hot water separation process for copper and insulating material recovery from electric cable waste. Waste Management \& Research, 18(5), 478-484. ISSN 0734-242X.

[38] YANG, L. et al. 2011. Recycling electrically-conductive metal and insulating material from cable waste by ultrasonic. In: Third International Conference on Measuring Technology and Mechatronics Automation (ICMTMA 2011): China, Shanghai, pp. 4-7. ISBN 978-0-7695-4296$6 / 11$.

[39] CELIK, C. et al. 2019. Recycling of waste electrical cables. Material Science \& Engineering International Journal, 3(4), 107-111. ISSN 2574-9927. 
[40] CUI, J., FORSSBERG, E. 2003. Mechanical recycling of waste electric and electronic equipment: A review. Journal of Hazardous Materials, B99, 243-263. ISSN 0304-3894.

[41] BEZERRA DE ARAÚJO, M. C. P. et al. 2008. Electronic scraps - Recovering of valuable materials from parallel wire cables. Waste Management, 28, 2177-2182. ISSN 0956-053X.

[42] VERMEŞAN, H. et al. 2020. Advanced recovery techniques for waste materials from IT and telecommunication equipment printed circuit boards. Sustainability, 12(1), 1-23. EISSN 20711050.

[43] ZEGHLOUL, T. et al. 2015. Corona-assisted plate-type electrostatic separation process for granular plastic wastes. In: 2015 IEEE Industry Applications Society Annual Meeting: USA, Addison, TX, pp. 1-6. ISBN 978-1-4799-8374-0.

[44] PARK, C. H. et al. 2015. Separation of covering plastics from particulate copper in cable wastes by induction electrostatic separation. Materials Transactions, 56(7), 1140-1143. ISSN 13475320.

[45] RICHARD, G. et al. 2017. Optimization of metals and plastics recovery from electric cable wastes using a plate-type electrostatic separator. Waste Management, 60, 112-122. ISSN 0956-053X.

[46] VinylPlus. 2014. PVC recycling technologies. [Online]. 2014 [Accessed: 03-2021] Available at https://www.eswa.be/pdf/OK_brochure_PVC_14-03-2014.pdf.

[47] LAMBERT, F. et al. 2015. Copper leaching from waste electric cables by biohydrometallurgy. Minerals Engineering, 76, 38-46. ISSN 0892-6875.

[48] ANASTASSAKIS, G. N. et al. 2015. Recovery of residual copper from low-content tailings derived from waste electrical cable treatment. International Journal ofMineral Processing, 143, 105-111. ISSN 0301-7516.

[49] KUMAR, $\mathrm{H}$. et al. 2020. Highly efficient recovery of high-purity $\mathrm{Cu}, \mathrm{PVC}$, and phthalate plasticizer from waste wire harnesses through PVC swelling and rod milling. Reaction Chemistry \& Engineering, 9, 1805-1813. ISSN 2058-9883.

[50] CONESA, J. A. et al. 2013. Decomposition of two types of electric wires considering the effect of the metal in the production of pollutants. Chemosphere, 91, 118-123, 2013. ISSN 0045-6535.

[51] ZABŁOCKA-MALICKA, M. et al. 2015. Recovery of copper from PVC multiwire cable waste by steam gasification. Waste Management, 46, 488-496. ISSN 0956-053X.

[52] SALAMA, A. et al. 2018. Distinct recovery of copper and aluminum from waste electric wires using a roll-type electrostatic separator. Waste Management, 76, 207-216. ISSN 0956-053X.

[53] DHOLU, N. et al. 2017. Current Separation of Nonferrous Metals Using a Variable-Frequency Electromagnet. KONA Powder and Particle Journal, 34, 241-247. ISSN 2187-5537.

[54] www.steinertglobal.com, Cable recovery: High-resolution optical sorting system for pure copper products. [Online]. [Accessed: 03-2021] Available at https://steinertglobal.com/metalrecycling/cable-recycling/.

[55] PARK, C. H. et al. 2007. PVC removal from mixed plastics by triboelectrostatic separation. Journal of Hazardous Materials, 144, 470-476. ISSN 0304-3894.

[56] DODBIBA, G. et al. 2005. The use of air tabling and triboelectric separation for separating a mixture of three plastics. Minerals Engineering, 18(15), 1350-1360. ISSN 0892-6875.

[57] TAKOUNGSAKDAKUN, T., PONGSTABODEE, S. 2007. Separation of mixed post-consumer PET-POM-PVC plastic waste using selective flotation. Separation and Purification Technology, 54(2), 248-252. ISSN 1383-5866.

[58] ABBASI, M. et al. 2010. Selective separation of PVC from PET/PVC mixture using floatation by tannic acid depressant. Iranian Polymer Journal, 19(7), 483-489. ISSN 1026-1265.

[59] ANZANO, J. et al. 2008. Classification of polymers by determining of $\mathrm{C}_{1}: \mathrm{C}_{2}: \mathrm{CN}: \mathrm{H}: \mathrm{N}: \mathrm{O}$ ratios by laser-induced plasma spectroscopy (LIPS). Polymer Testing, 27(6), 705-710. ISSN 01429418.

[60] GONDAL, M. A., SIDDIQUI, M. N. 2007. Identification of different kinds of plastics using laserinduced breakdown spectroscopy for waste management. Journal of Environmental Science and Health - Part A Toxic/Hazardous Substances and Environmental Engineering, 42(13), 19891997. ISSN 1093-4529.

[61] Ministry of Environment of the Slovak Republic. Waste Management Plan of the Slovak Republic for 2016-2020. [Online]. [Accessed: 03-2021] Available at https://www.minzp.sk/files/sekcia- 
enviromentalneho-hodnotenia-riadenia/odpady-a-obaly/registre-a-zoznamy/poh-sr-20162020_vestnik_en-2.pdf.

[62] District Office Bratislava. Decision of the authoritz for WIP Autovrakovisko s.r.o. [Online]. 2016 [Accessed: 03-2021] Available at https://wip-autovrakovisko.sk/wp-content/uploads/Suhlas.pdf.

[63] www.procas.sk, Recycling of copper and aluminium cable waste (Recyklácia káblového odpadu na báze medi alebo hliníka klasifikovaného ako nie nebezpečný odpad). [Online]. [Accessed: 032021] Available at http://www.procas.sk/.

[64] www.kovozber.sk, Evaluation of cables with copper $(\mathrm{Cu})$ and aluminum (Al) conductors (Zhodnotenie káblov s medenými $(\mathrm{Cu})$ a hliníkovými $(\mathrm{Al})$ vodičmi). [Online]. [Accessed: 032021] Available at https://www.kovozber.sk/recyklacia/cu-al-kable/.

[65] www.schoolofsustainability.it, Efficient managing waste is the first step towards a circular economy. [Online]. 2019 [Accessed: 03-2021] Available at https://www.schoolofsustainability.it/efficient-managing-waste-is-the-first-step-towards-acircular-economy/.

[66] SCHAFFNER, E. Circular economy. [Online]. 2020 [Accessed: 03-2021] Available at https://medium.com/@zeloop/circular-economy-5ac5583c7eb1.

[67] RAHMAN, S. M. M., KIM, J. 2020. Circular economy, proximity, and shipbreaking: A material flow and environmental impact analysis. Journal of Cleaner Production, 259, 120681. ISSN 0959-6526.

[68] LEMILLE, A. For a true circular economy, we must redefine waste. [Online]. 2019 [Accessed: 03-2021] Available at https://www.weforum.org/agenda/2019/11/build-circular-economy-stoprecycling/.

[69] European commission. Waste and Circular Economy. [Online]. 2020 [Accessed: 03-2021] Available at https://ec.europa.eu/jrc/en/research-topic/waste-and-recycling.

[70] BARRA, R. et al. 2018. Plastics and the circular economy (A STAP document). [Online]. [Accessed: 03-2021] Available at https://stapgef.org/sites/default/files/202002/PLASTICS\%20for\%20posting.pdf?null=.

[71] HYSA, E. et al. 2020. Circular economy innovation and environmental sustainability impact on economic growth: An integrated model for sustainable development. Sustainability, 12(12). ISSN 2071-1050.

[72] www.dnr.wi.gov, Keepin' it in the loop : a recycling activity and learning guide for educators and students, grades K-8. [Online]. 2011 [Accessed: 03-2021] Available at https://dnr.wi.gov/files/pdf/pubs/wa/wa1526.pdf.

[73] RITCHIE, H. FAQs on Plastics. [Online]. 2018 [Accessed: 03-2021] Available at https://ourworldindata.org/faq-on-plastics\#what-are-the-environmental-impacts-of-landfills.

[74] MAKULEKE, P., NGOLE-JEME, V. M. 2020. Soil Heavy Metal Distribution with Depth around a Closed Landfill and Their Uptake by Datura stramonium. Applied and Environmental Soil Science, 2020. ISSN 1687-7667.

[75] TETA, C., HIKWA, T. 2017. Heavy metal contamination of ground water from an unlined landfill in Bulawayo, Zimbabwe. Journal of Health and Pollution, 7(15), 18-27. ISSN 2156-9614.

[76] www.vinylplus.de, Everything about PVC from manufacturing to recycling. [Online]. 2016 [Accessed: 03-2021] Available at https://www.vinylplus.de/wpcontent/uploads/2018/01/AGPU_Everything-About-PVC_en.pdf.

[77] KALEY, K. B. et al. 2006. Health Concerns and Environmental Issues with PVC-Containing Building Materials in Green Buildings. p. 77. [Online]. [Accessed: 03-2021] Available at https://www2.calrecycle.ca.gov/Publications/Download/829?opt=dln.

[78] BELLIVEAU, M., LESTER, S. 2004. PVC Bad news comes in s The Poison Plastic, Health Hazards an the Looming Waste Crisis. p. 100. [Online]. [Accessed: 03-2021] Available at http://chej.org/wp-content/uploads/PVC\%20$\% 20 \mathrm{Bad} \% 20 \mathrm{News} \% 20 \mathrm{Comes} \% 20 \mathrm{in} \% 203 \% 27 \mathrm{~s} \% 20-\% 20 \mathrm{REP} \% 20005$.pdf.

[79] CORREA, C. A. et al. 2019. Green-PVC with full recycled industrial waste and renewably sourced content. Journal of Cleaner Production journal, 229, 1397-1411. ISSN 0959-6526.

[80] CESARO, A. et al. 2019. A relative risk assessment of the open burning of WEEE. Environmental Science and Pollution Research, 26, 11042-11052. ISSN 1614-7499. 
[81] CHO, R. What Can We Do About the Growing E-waste Problem? [Online]. 2018 [Accessed: 032021] Available at https://blogs.ei.columbia.edu/2018/08/27/growing-e-waste-problem/.

[82] FORTI, V. et al. 2020. The Global E-waste Monitor 2020: Quantities, Flows, and the Circular Economy Potential, p. 120. ISBN: 978-92-808-9114-0. [Online]. [Accessed: 03-2021] Available at https://www.itu.int/en/ITU-D/Environment/Documents/Toolbox/GEM_2020_def.pdf

[83] TEAGUE, L. The Advantages of Recycling Copper. [Online]. 2017 [Accessed: 03-2021] Available at https://sciencing.com/advantages-recycling-copper-6319076.html.

[84] Copper Development Association. Copper Recycling and Sustainability 2. [Online]. [Accessed: 03-2021] Available at https://copperalliance.org.uk/knowledge-base/education/educationresources/copper-recycling-sustainability-2/.

[85] BATERMA, C. Is Recycling Copper Good for the Environment? [Online]. 2017 [Accessed: 032021] Available at https://sciencing.com/recycling-copper-good-environment-18437.html.

[86] www.roanemetals.com, Environmental \& Economic Benefits of Copper Recycling, [Online]. [Accessed: 03-2021] Available at https://roanemetals.com/benefits-of-copper-recycling/.

[87] www.vycomplastics.com, 3 Benefits of Recycled PVC Equal Endless Opportunities. [Online]. [Accessed: 03-2021] Available at https://www.vycomplastics.com/blog/3-benefits-of-recycledpvc-equal-endless-opportunities/.

[88] www.vinylplus.eu, Sustainable \& Recyclable. [Online]. [Accessed: 03-2021] Available at https://vinylplus.eu/recycling/a-smart-material/sustainable-recyclable.

[89] www.euric-aisbl.eu, Plastic Recycling Factsheet. [Online]. Available: https://www.euricaisbl.eu/position-papers/download/680/381/32.

[90] www.vinylplus.eu, Why recycle? [Online]. [Accessed: 03-2021] Available at https://vinylplus.eu/recycling/a-smart-material/why-recycle.

[91] www.vinyloop.com, VinyLoop White paper. [Online]. 2012 [Accessed: 03-2021] Available at https://pieweb.plasteurope.com/members/pdf/p223847a.PDF.

[92] www.cablerecyclingmachinery.com, Waste Cables/Wires Stripping Machine. [Online]. [Accessed: 06-2021] Available at https://www.cablerecyclingmachinery.com/waste-cablesrecycling-plant/waste-cables-wires-stripping-machine.html.

[93] www.copperwirerecyclingmachinery.com, Is it possible for copper wire recycling machine to recycle different kinds of waste wires and cables? [Online]. [Accessed: 06-2021] Available at https://www.copperwirerecyclingmachinery.com/news/recycle_different_kinds_of_waste_wires _and_cables790.html.

[94] www.indiamart.com, Electric Wire Scrap. [Online]. [Accessed: 06-2021] Available at https://www.indiamart.com/proddetail/electric-wire-scrap-21207742262.html.

[95] www.indiamart.com, Standard Waste Cable Stripping Machine, Automation Grade: SemiAutomatic [Online]. [Accessed: 06-2021] Available at https://www.indiamart.com/proddetail/waste-cable-stripping-machine-20990770930.html.

[96] www.changwoen.com, Cable Wires Recycling Machine. [Online]. [Accessed: 06-2021] Available at https://www.changwoen.com.tw/Cable-Wires-Recycling-Machine.html.

[97] www.scrap-wire-stripper.com, Electric Copper Wire Scrap Stripping Machine. [Online]. [Accessed: 06-2021] Available at https://www.scrap-wire-stripper.com/cable-strippingmachine/45995562.html.

[98] www.cablerecyclingmachinery.com, Waste Cables/Wires Stripping Machine. [Online]. [Accessed: 06-2021] Available at https://www.cablerecyclingmachinery.com/waste-cablesrecycling-plant/waste-cables-wires-stripping-

machine.html?gclid=Cj0KCQjw8IaGBhCHARIsAGIRRYoGOJnrLOcG7kzae4tGyqtls2tBTq8 CrrU0rwjAjs06aSAe86mjUXEaAqkTEALw_wcB.

[99] www.cablerecyclingmachinery.com, Copper Wire Recycling System. [Online]. [Accessed: 062021] Available at https://www.cablerecyclingmachinery.com/waste-cables-recyclingplant/copper-wire-recycling-system.html.

[100] www.sunygroup.cn, Scrap Cable Wire Recycling Crushing Separating Machine. [Online]. [Accessed: 06-2021] Available at https://www.sunygroup.cn/products/Recycling_equipment/810.html.

[101] www.aggrowth.com, Gravity Separator. [Online]. [Accessed: 06-2021] Available at https://www.aggrowth.com/en-us/brands/milltec-machinery/gravity-separator. 
[102] www.sssdynamics.com, Gravity Separators. [Online]. [Accessed: 06-2021] Available at https://www.sssdynamics.com/equipment/density-separation/sutton-gravity-separators/.

[103] www.copper-recycle.com, Air gravity separator. [Online]. [Accessed: 06-2021] Available at https://copper-recycle.com/recycling-machines/separator/metal-separator.html.

[104] PITA, F., CASTILHO, A. 2018. Separation of Copper from Electric Cable Waste Based on Mineral Processing Methods: A Case Study. Minerals, 8(11), 517. EISSN 2075-163X.

[105] www.oecd.org, Recycling of copper, lead and zinc bearing wastes (Environment monographs $\mathrm{N}^{\circ}$ 109). [Online]. 1995. [Accessed: 06-2021] Available at https://www.oecd.org/officialdocuments/publicdisplaydocumentpdf/?cote=OCDE/GD(95)78\&d ocLanguage $=$ En.

[106] www.chm.pops.int, Section VI Guidance/guidelines by source category: Source categories in Part III of Annex C. [Online]. 12/2006 [Accessed: 06-2021] Available at http://chm.pops.int/Portals/0/download.aspx?d=UNEP-POPS-BATBEP-GUID-GUIDELINES17.En.DOC.

[107] LASSESSON, H., 2013. Speciation of copper in ashes from municipal solid waste combustion. ISSN 1652-943X. [Online]. [Accessed: 06-2021] Available at https://publications.lib.chalmers.se/records/fulltext/174788/174788.pdf.

[108] KEBER, S. et al. 2020. Characterization of Fine Fractions from the Processing of Municipal Solid Waste Incinerator Bottom Ashes for the Potential Recovery of Valuable Metals. Minerals, 10(10), 838. EISSN 2075-163X.

[109] WAN, X. et al. A study on the chemical and mineralogical characterization of MSWI fly ash using a sequential extraction procedure. Journal of Hazardous Materials, 134(1-3), 197-201. ISSN 0304-3894.

[110] TAKAOKA, M. et al. 2005. Dynamic Change of Copper in Fly Ash during de Novo Synthesis of Dioxins. Environmental Science \& Technology. 2005, 39, 15, 5878-5884. ISSN 0013-936X.

[111] www.pdcable.com, Cable name: PHELPS DODGE CABLE TYPE 60227 IEC 01 (THW). [Online]. [Accessed: 06-2021] Available at https://www.pdcable.com/en/producten/60227-iec-01-thw-1-2/.

[112] www.pdcable.com, Cable name: PHELPS DODGE CABLE TYPE 60227 IEC 10. [Online]. [Accessed: 06-2021] Available at https://www.pdcable.com/en/product-en/60227-iec-10-1-2/.

[113] www.pdcable.com, Cable name: MEDIUM VOLTAGE CROSS-LINKED POLYETHYLENE CABLE. [Online]. [Accessed: 06-2021] Available at https://www.pdcable.com/en/producten/mxlp-cts-3-core-3/.

[114] www.pdcable.com, Cable name: 0.6/1(1.2) kV FIRE RESISTANT LOW SMOKE \& HALOGEN FREE. [Online]. [Accessed: 06-2021] Available at https://www.pdcable.com/en/product-en/frcmulti-core-2-2/.

[115] www.pdcable.com, Cable name: PHELPS DODGE CABLE TYPE CV-AWA. [Online]. [Accessed: 06-2021] Available at https://www.pdcable.com/en/product-en/lv/cv-awa-1-2/.

[116] www.pdcable.com, Cable name: MEDIUM VOLTAGE CROSS-LINKED POLYETHYLENE CABLE. [Online]. [Accessed: 06-2021] Available at https://www.pdcable.com/en/producten/mxlp-awa-1-2-2/.

[117] www.pdcable.com, Cable name: FIGURE 8 AL-PE SHEATHED CABLE. [Online]. [Accessed: 06-2021] Available at https://www.pdcable.com/en/product-en/building-and-construction/ap8$2 /$.

[118] www.elkond.sk, Catalogue of products. [Online]. [Accessed: 06-2021] Available at http://elkond.sk/wp-content/uploads/2016/02/katalog_elkond_04_2015_web.pdf.

[119] www.epa.gov, Chapter 1. Scope and boundaries. [Online]. [Accessed: 06-2021] Available at https://www.epa.gov/sites/production/files/2015-04/documents/wire_ch1.pdf.

[120] MARTINKA, J. et al. 2019. Heat of combustion as the key fire characteristics of electrical cables. Research papers Faculty of Materials Science and Technology Slovak University of Technology in Trnava, 27(44), 29-40. ISSN 1336-1589.

[121] ZABLOCKA-MALICKA, M. et al. 2015. Recovery of copper from PVC multiwire cable waste by steam gasification. Waste Management, 46, 488-496. ISSN 0956-053X. 
[122] HUANG, X. et al. 2018. Burning behavior of cable tray located on a wall with different cable arrangements. [Online]. [Accessed: 06-2021] Available at https://onlinelibrary.wiley.com/doi/full/10.1002/fam.2669.

[123] AKBARI, S., AHMADI, A. 2019. Recovery of copper from a mixture of printed circuit boards (PCBs) and sulphidic tailings using bioleaching and solvent extraction processes. Chemical Engineering and Processing - Process Intensification, 142, 107584. ISSN 0255-2701.

[124] XIAO, S. et al. 2016. The Treatment Technology of Recycling Scrap Wire and Cable. Proceedings of the 2015 4th International Conference on Sustainable Energy and Environmental Engineering. [Online]. [Accessed: 06-2021] Available at https://www.atlantispress.com/proceedings/icseee-15/25849765. ISSN 2352-5401.

[125] TRAN, CH. D., SALHOFER, S. P. 2018. Processes in informal end-processing of e-waste generated from personal computers in Vietnam. Journal of Material Cycles and Waste Management, 20, 1154-1178, ISSN 1611-8227.

[126] WILLIAMS, J. 2020. What is a wire stripping machine and why you should consider buying one? [Online]. [Accessed: 06-2021] Available at https://www.bluedogwirestripper.com/blog/what-isa-wire-stripping-machine-and-why-you-should-consider-buying-one/.

\section{ORCID}

Lenka Blinová

0000-0001-6971-6558

Peter Godovčin

0000-0003-4531-417X 